\title{
Anatomic Characterization and Photosynthetic Rate in Cotton Genotypes due the Mepiquat Chloride
}

\author{
Amanda Pereira Paixão ${ }^{1}$, Aline Redondo Martins ${ }^{1}$, Simone Silva Hiraki ${ }^{2}$, Liliane Santos de Camargos $^{1}$, \\ Luis Henrique Marani Daruichi Machado ${ }^{1}$, Mariana Yamada ${ }^{1}$ \& Enes Furlani Jr. ${ }^{1}$ \\ ${ }^{1}$ São Paulo State University (UNESP), School of Engineering, Ilha Solteira, SP, Brazil \\ ${ }^{2}$ Instituto Federal de Mato Grosso do Sul, Campus de Ponta Porã, Ponta Porã, MS, Brazil \\ Correspondence: Enes Furlani Jr., São Paulo State University (UNESP), School of Engineering, Ilha Solteira, \\ Department of Fitotecnia Tecnologia de Alimentos e Socioecomia, Av Brasil 56, Ilha Solteira, SP, Brazil. Tel: \\ 55-18-3543-1144. E-mail: enes@agr.feis.unesp.br
}

Received: August 9, 2017

doi:10.5539/jas.v9n12p122

\author{
Accepted: October 9, $2017 \quad$ Online Published: November 15, 2017
}

URL: https://doi.org/10.5539/jas.v9n12p122

\begin{abstract}
The FMT 701 and Fibermax 966 genotypes of the herbaceous cotton plants showed distinct morphophysiological characteristics due to their unique genetics. Henceforth, they are likely to have differences both in the foliar anatomic characters and in the photosynthetic apparatus due to the application of the mepiquat chloride (MC) growth regulator. The goal of the present work was to assess two genotypes of cotton plants with unique genetic characteristics through the application of increasing doses of MC by means of anatomic analyses of the foliar limb. The experiment was led in field conditions in the region of Cerrado, and experimental delineation employed was the randomized blocks, in a $5 \times 2$ factorial scheme totaling 10 treatments, with 4 repetitions making up a total of 40 parcels. MC was applied through foliar route, parceled in three applications performed 50,60 and 70 days after the emergence, and such treatments consisted of the application of fours doses of MC $\left(500 ; 1,000 ; 1,500 ; 2,500 \mathrm{~mL} \mathrm{ha}^{-1}\right)$ and a witness. The results obtained from the FMT 701 and Fibermax 966 genotypes suggest that MC exerted distinct influence upon the thicknesses of the adaxial and abaxial epidermises, palisade and lacuna parenchyma and the total thickness of both the internervural region and the region next to the central nervure. The number of adaxial stomata was reduced due to the doses of MC, exerting influence upon the photosynthetic rate in both genotypes.
\end{abstract}

Keywords: Gossypium hirsutum L. var. latifolium Hutch, growth regulator, leaf thickness

\section{Introduction}

The herbaceous cotton (Gossypium hirsutum L. var. latifolium Hutch) is a plant that has high morphological and genetic complexity. Displays photosynthetic metabolism of type C3 with high rate of photorespiration, which can exceed $40 \%$ of the gross photosynthesis, depending on the environment, particularly the temperature and light (Taiz \& Zeiger, 2010).

Since cotton is a plant with indeterminate growth habit, research with the use of growth regulators limiting vegetative growth to occur larger displacement of metabolites to useful drains from the economic view. Therefore, aiming the high levels of field productivity, among other factors, it is important to the balance between vegetative and reproductive growth and development that is sequential in nature (Beltrão et al., 1997).

Among the factors responsible for the cotton plant productivity, the use of growth regulators is highlighted, from where mepiquat chloride stands out (MC). Mepiquat chloride is an inhibiting product of the biosynthesis of gibberellins, plant hormones responsible for growth (Constable, 1994), which reduce plant height and standardize fruit opening, thus facilitating the mechanical harvest (Barbosa \& Castro, 1983).

Gausman et al. (1979) observed that applications of different doses of MC when the plants had grown seven leaves provided increases in leaf size, reduction in the foliar region, more stretched palisade cells and a greater number of lacuna parenchyma cells. They also observed that the chlorophyll concentration increased, whereas the $a / b$ chlorophyll ratio diminished. Such results point to changes in the energy ratios within the leaves, influencing the photosynthetic efficiency. 
According to Fundação Mato Grosso (2012), the genotype FMT 701 presents tall structure $(1.70 \mathrm{~m})$ and late mid-cycle. It is highly responsive and adapted to mehanical harvest and also has good fiber quality. On the other hand, according to Bayer CropScience (2012), the genotype Fibermax 966 presents short structure (0.90 to 1.20 $\mathrm{m})$, early cycle, high-quality fiber, industrial yielding and lower use of growth regulator.

This way, the present work aimed at assessing the anatomic and photosynthetic aspects of the foliar limb in the FMT 701 and Fibermax 966 genotypes of the cotton plants, with specific genetic characteristics, due to the application of increasing doses of MC.

\section{Material and Methods}

\subsection{Experimental Design}

The experiment was developed in the experimental area of the teaching, research and extension farm of the college of engineering, UNESP/Ilha Solteira campus, located in the town of Selviria - MS, in the agricultural year of 2013. The geographic coordinates of the area under study are $20^{\circ} 20^{\prime}$ South latitude and $51^{\circ} 24^{\prime}$ West longitude with average altitude of $344 \mathrm{~m}$. The weather is classified as the Aw type, according to Köppen, and is defined as humid tropical with rainy season in summer and drought in winter. Also, it shows annual average temperature of $24.5{ }^{\circ} \mathrm{C}$, annual average precipitation of $1,232 \mathrm{~mm}$ and average relative humidity of $64.8 \%$ (Hernandez et al., 1995).

The area soil has been classified as very loamy dystrophic red latosol, with the following chemical characteristics: Presine $29 \mathrm{mg} / \mathrm{dm}^{3}$, organic matter $21 \mathrm{~g} / \mathrm{dm}^{3}, \mathrm{pH} 5.3,69 \%$ of saturation by bases and 3.5, 38, 22, 29, 0 and $92.5 \mathrm{mmol}_{\mathrm{c}} / \mathrm{dm}^{3}$ of $\mathrm{K}, \mathrm{Ca}, \mathrm{Mg}, \mathrm{H}+\mathrm{Al}, \mathrm{Al}$ and $\mathrm{CTC}$, respectively. The area was prepared with moldboard plow and grid and the saturation by bases was increased to $70 \%$.

The treatments were composed of four doses of MC $\left(500 ; 1,000 ; 1,500 ; 2,500 \mathrm{ml} \mathrm{ha}^{-1}\right)$ and a witness, using the commercial product Pix $\mathrm{HC}^{\circledR}\left(250 \mathrm{~g} \mathrm{~L}^{-1}\right)$. The experimental delineation employed was the randomized blocks, in a $5 \times 2$ factorial scheme totaling 10 treatments, with 4 repetitions making up a total of 40 parcels, composed of four culture lines with five meters of length and $0.9-\mathrm{m}$ spacing; the usable area consisted of the two central lines of the parcel.

The growth regulator whose active principle is $\mathrm{MC}\left(250 \mathrm{~g} \mathrm{~L}^{-1}\right)$ was applied by means of foliar spraying in the FMT 701 and FiberMax 966 genotypes with a $\mathrm{CO}_{2}$-based knapsack sprayer with constant pressure, coupled with XR11002 spraying tips, pressure calibrated at three bar and spraying volume of 160 liters per hectare. The volume was divided into three applications made 50,60 and 70 days after the emergence (DAE). The cotton plant genotypes were sown mechanically on days $21 / 12 / 12$, in the direct seeding system, and the seedling emergence happened after 5 days. $30 \mathrm{DAE}$, thinning was performed, leaving eight plants per meter. The FMT 701 genotype is high $(1.70 \mathrm{~m})$, has average-late life cycle. On the other hand, the Fibermax 966 genotype is low ( 0.90 to $1.20 \mathrm{~m})$, has precocious life cycle.

\subsection{Leaf Anatomic}

80 days after the emergence, the samples of the middle third of the foliar limb were collected, comprehending the regions of the central and internervural nervure, fixed in FAA 50 (formaldehyde + glacial acetic acid + alcohol 50\%), during $48 \mathrm{~h}$. They were further conserved in alcohol 70\% (Johansen, 1940). The foliar material samples were dehydrated in ascending ethyl alcohol series and were then included in hydroxyethyl-methacrylate (Leica Historesin). Cross sections were made with thickness between 8 and $10 \mu \mathrm{m}$, using a rotary microtome. The sections underwent staining with Toluidine blue $0.05 \%$ in phosphate and citric acid buffer, $\mathrm{pH}$ between 4.5-6.0 (Sakai, 1973) and were then mounted on "Entellan" synthetic resin.

Regarding the quantification of the anatomic structures present in the foliar limb, the following quantitative characters of the regions of the central and internervural nervure were assessed: epidermis of the adaxial and abaxial faces, palisade and lacuna parenchyma and number of stoma.

The photomicrographs were made on a photomicroscope, with the micrometrical scales photographed and magnified in the same optical conditions used. Photonic Bel trinocular microscope was also used, coupled to the camera devide of the Moticam 1000 of 1.3 M Pixel model, and the images were captured on the micro-computer.

\subsection{Gas Exchange Parameters}

The liquid photosynthetic rates (difference between the gross photosynthesis and breathing (Raven et al., 2007)) expressed per area $\left(\mathrm{A}-\mu \mathrm{mol} \mathrm{CO}_{2} \mathrm{~m}^{-2} \mathrm{~s}^{-1}\right)$, stoma conductance $\left(\mathrm{g}_{\mathrm{s}}-\mathrm{mol} \mathrm{H}_{2} \mathrm{O} \mathrm{m}^{-2} \mathrm{~s}^{-1}\right)$ and internal concentration of $\mathrm{CO}_{2}\left(\mathrm{C}_{\mathrm{i}}-\mu \mathrm{mol} \mathrm{CO} \mathrm{CO}_{2} \mathrm{~mol} \mathrm{ar^{-1 }}\right)$ were assessed using a portable device for gas exchanges, (Infra Red Gas Analyser - IRGA, ADC BioScientific Ltd brand, LC-Pro model). The conditions initially established for the 
measurements were $1,000 \mu \mathrm{mol} \mathrm{m} \mathrm{m}^{-2}$ of photosynthetic active radiation (PAR), provided by LED lamps; 380 ppm of $\mathrm{CO}_{2}$ and chamber temperature at $28^{\circ} \mathrm{C}$. The measurement of gas exchanges was performed one day after the last application of MC, on 71 DAE, on sunny days, in the period between 08:00 AM and 12:00 PM, taking the $2^{\text {nd }}$ or $3^{\text {rd }}$ fully expanded adult leaf from the end of the branch.

The data obtained underwent variance analysis through the $\mathrm{F}$ test. For the genotypes, the characteristics assessed underwent Tukey's test at 5\% probability and regression analysis for the doses, where both linear and quadratic models were tested. When there was significant interaction between the doses and the genotypes, unfolding was performed and the regression equation that best fit the data was adopted, which was chosen based on the significance of the regression coefficients at $1 \%(* *)$ and $5 \%\left(^{*}\right)$ of probability through the $\mathrm{F}$ test (Gomes, 2000) and higher value of the determination coefficients $\left(\mathrm{R}^{2}\right)$, by means of the Sisvar statistic software (Ferreira, 2000), thus achieving the dose calculated.

\section{Results}

According to the data shown in Table 1, regarding the thickness of the foliar interneurvural region, it was confirmed that the genotypes are as thick as the adaxial epidermis, abaxial epidermis, palisade parenchyma and lacuna parenchyma. However, the FMT 701 genotype showed the same foliar total thickness higher than Fibermax 966. There was interaction of the doses of MC $\times$ genotypes for all characteristics assessed (Tables 1.1, $1.2,1.3,1.4$ and 1.5$)$ respectively.

Table 1. Thickness of the parameters $(\mu \mathrm{m})$ of the foliar intervural region of the genotypes of the herbaceous cotton plant according to ascending doses of mepiquat chloride, agricultural year 2013. The data regarding the genotypes were expressed based on the average of all the doses within each genotype. The data for the doses were expressed as the mean of the genotypes within the same dose

\begin{tabular}{llllll}
\hline Genotypes & Adaxial epidermis & Abaxial epidermis & Palisade parenchyma & Lacuna Parenchyma & Total thickness \\
\hline FMT 701 & $25.82 \mathrm{a}$ & $20.80 \mathrm{a}$ & $161.49 \mathrm{a}$ & $111.41 \mathrm{a}$ & $319.74 \mathrm{a}$ \\
$\begin{array}{l}\text { Fibermax } 966 \\
\text { Doses }\end{array}$ & $25.03 \mathrm{a}$ & $20.10 \mathrm{a}$ & $157.78 \mathrm{a}$ & $108.52 \mathrm{a}$ & $309.57 \mathrm{~b}$ \\
0 & & & & & \\
500 & 27.44 & 20.60 & 181.54 & 123.32 & 351.64 \\
1000 & 25.96 & 20.92 & 146.60 & 95.58 & 288.72 \\
1500 & 24.00 & 21.02 & 145.94 & 102.61 & 284.39 \\
2500 & 24.06 & 17.69 & 153.53 & 114.69 & 317.55 \\
\hdashline SD & 25.66 & 22.02 & 170.56 & 113.63 & 330.98 \\
CV (\%) & 5.26 & 4.70 & 31.75 & 24.29 & 43.98 \\
\hline
\end{tabular}

Note. Means followed by the same vertical letter do not differ through Tukey's test at 5\% probability. SD: Standard deviation. CV (\%): Coefficient of variation.

Regarding the adaxial epidermis (Table 1.1), there was significant difference among the genotypes only in the dose of $500 \mathrm{~mL} \mathrm{ha}^{-1}$, which increased the FMT 701 thickness and decreased that of Fibermax 966. In the FMT 701 genotype in the calculated dose of $1397 \mathrm{~mL} \mathrm{ha}^{-1}$ there was a greater decrease in the adaxial epidermis thickness, $13.72 \%$ compared to the witnesses. In Fibermax 966 in the calculated dose of $2071.5 \mathrm{~mL} \mathrm{ha}^{-1}$ there was greater decrease in the adaxial epidermis thickness, $16.02 \%$ when compared to the witnesses.

The thickness of the abaxial epidermis differed between genotypes in the witness plants and in the dose of 2500 $\mathrm{mL} \mathrm{ha}^{-1}$, with thickness higher in FMT 701 (Table 1.2). In FMT 701 the values of the abaxial epidermis thickness tended to decrease according to the doses of $\mathrm{MC}$, in the calculated dose of $1416 \mathrm{~mL} \mathrm{ha}^{-1}$ there was a greater decrease in thickness, $17.88 \%$, when compared to the witnesses. In Fibermax 966, it was confirmed overall that the MC doses increased the thickness of the abaxial epidermis, and the greatest increase was in the dose of $1000 \mathrm{~mL}$ $\mathrm{ha}^{-1}, 10.76 \%$. The only dose that decreased the abaxial epidermis thickness of Fibermax 966 was $1500 \mathrm{~mL} \mathrm{ha}^{-1}$, $8.55 \%$.

Regarding the palisade parenchyma, there was significant difference between the genotypes in the witness plants, with greater values in FMT 701 and in the doses of $1.000 \mathrm{~mL} \mathrm{ha}^{-1}$ and $1,500 \mathrm{~mL} \mathrm{ha}^{-1}$ (Table 1.3). Also, in these doses FMT 701 presented the palisade parenchyma thickness lower than did Fibermax 966, suggesting that these does decreased the FMT 701 thickness and increased that of Fibermax 966. In FMT 701, the palisade parenchyma 
decreased according to the MC doses and in the calculated dose of $1427.7 \mathrm{~mL} \mathrm{ha}^{-1}$ there was the lowest thickness, reduction of $38.36 \%$ compared to the witnesses. In Fibermax 966 there was an increase in the thickness of the palisade parenchyma due to the functions of the MC doses, having the largest increase in the dose of $2500 \mathrm{~mL} \mathrm{ha}^{-1}$, $13.59 \%$ higher than the thickness of the palisade parenchyma of the witnesses.

For the lacuna parenchyma, there was difference between the genotypes in the witness plants. FMT 701 showed larger thickness, and in the doses of $500 \mathrm{~mL} \mathrm{ha}^{-1}$ and $1500 \mathrm{~mL} \mathrm{ha}^{-1}$, with the decrease in the thickness of FMT 701 and increase in Fibermax 966 (Table 1.4). In FMT 701, it was possible to verify that the thickness of the lacuna parenchyma decreased due to the MC doses, and in the calculated dose of $1249.2 \mathrm{~mL} \mathrm{ha}^{-1}$ there was a smaller thickness of the lacuna parenchyma, 30.41\% lower than the thickness of the witnesses. On the other hand, an increase in the thickness of the lacuna parenchyma in Fibermax 966 was observed due to the MC doses, and in the calculated dose of $1743.6 \mathrm{~mL} \mathrm{ha}^{-1}$ there was a larger thickness of the lacuna parenchyma, $15.83 \%$ higher than that of the witness.

Regarding the total thickness (Table 1.5), there was difference between the genotypes in the witness plants, with the larger thickness of FMT 701, and in the doses of $1,000 \mathrm{~mL} \mathrm{ha}^{-1}$ and $1500 \mathrm{~mL} \mathrm{ha}^{-1}$, with larger thickness of Fibermax 966, once that these doses decreased the thickness of FMT 701 and increased that of Fibermax 966. In FMT 701, it was possible to confirm that all MC doses decreased the leaf total thickness, and in the calculated dose of $1371.9 \mathrm{~mL} \mathrm{ha}^{-1}$ there was the smallest thickness, $31.79 \%$ smaller than that of the witnesses. However, the opposite happened in Fibermax 966: all MC doses increased the leaf total thickness, with a larger increase in this thickness in the dose of $1500 \mathrm{~mL} \mathrm{ha}^{-1}, 13.75 \%$.

Table 1.1. Unfolding of the interaction of increasing doses of mepiquar chloride $\times$ herbaceous cotton genotypes, refers to the thickness of the leaves adaxial epidermis (intervervural) collected at 80 DAE. Selvíria-MS, Agricultural year 2013

\begin{tabular}{lll}
\hline Doses & FMT 701 & Fibermax 966 \\
\hline 0 & $27.66 \mathrm{a}$ & $27.23 \mathrm{a}$ \\
500 & $28.01 \mathrm{a}$ & $23.91 \mathrm{~b}$ \\
1000 & $23.37 \mathrm{a}$ & $24.63 \mathrm{a}$ \\
1500 & $24.12 \mathrm{a}$ & $23.99 \mathrm{a}$ \\
2500 & $25.92 \mathrm{a}$ & $25.40 \mathrm{a}$ \\
\hline
\end{tabular}

Note. Means followed by the same vertical letter do not differ through Tukey's test at $5 \%$ probability.

Table 1.2. Unfolding of the interaction of increasing doses of mepiquar chloride $\times$ herbaceous cotton genotypes, refers to the leaves abaxial epidermis (intervervural) collected at 80 DAE. Selvíria-MS, Agricultural year 2013

\begin{tabular}{lll}
\hline Doses & FMT 701 & Fibermax 966 \\
\hline 0 & $21.81 \mathrm{a}$ & $19.40 \mathrm{~b}$ \\
500 & $20.76 \mathrm{a}$ & $21.09 \mathrm{a}$ \\
1000 & $20.30 \mathrm{a}$ & $21.74 \mathrm{a}$ \\
1500 & $17.64 \mathrm{a}$ & $17.74 \mathrm{a}$ \\
2500 & $23.51 \mathrm{a}$ & $20.53 \mathrm{~b}$ \\
\hline
\end{tabular}

Note. Means followed by the same vertical letter do not differ through Tukey's test at $5 \%$ probability.

Table 1.3. Unfolding of the interaction of increasing doses of mepiquar chloride $\times$ herbaceous cotton genotypes, refers to the leaves palisade parenchyma (intervervural) collected at 80 DAE. Selvíria-MS, Agricultural year 2013

\begin{tabular}{lll}
\hline Doses & FMT 701 & Fibermax 966 \\
\hline 0 & $216.06 \mathrm{a}$ & $147.03 \mathrm{~b}$ \\
500 & $146.69 \mathrm{a}$ & $146.52 \mathrm{a}$ \\
1000 & $129.98 \mathrm{a}$ & $161.90 \mathrm{~b}$ \\
1500 & $143.78 \mathrm{a}$ & $163.28 \mathrm{~b}$ \\
2500 & $170.96 \mathrm{a}$ & $170.16 \mathrm{a}$ \\
\hline
\end{tabular}

Note. Means followed by the same vertical letter do not differ through Tukey's test at $5 \%$ probability. 
Table 1.4. Unfolding of the interaction of increasing doses of mepiquar chloride $\times$ herbaceous cotton genotypes, refers to the leaves lacuna parenchyma (intervervural) collected at 80 DAE. Selvíria-MS, Agricultural year 2013

\begin{tabular}{lll}
\hline Doses & FMT 701 & Fibermax 966 \\
\hline 0 & $148.11 \mathrm{a}$ & $98.53 \mathrm{~b}$ \\
500 & $85.80 \mathrm{a}$ & $105.37 \mathrm{~b}$ \\
1000 & $99.81 \mathrm{a}$ & $105.41 \mathrm{a}$ \\
1500 & $107.30 \mathrm{a}$ & $122.08 \mathrm{~b}$ \\
2500 & $116.05 \mathrm{a}$ & $111.20 \mathrm{a}$ \\
\hline
\end{tabular}

Note. Means followed by the same vertical letter do not differ through Tukey's test at 5\% probability.

Table 1.5. Unfolding of the interaction of increasing doses of mepiquar chloride $\times$ herbaceous cotton genotypes, refers to the total thickness (intervervural) of leaves collected at 80 DAE. Selvíria-MS, Agricultural year 2013

\begin{tabular}{lll}
\hline Doses & FMT 701 & Fibermax 966 \\
\hline 0 & $410.84 \mathrm{a}$ & $292.45 \mathrm{~b}$ \\
500 & $280.76 \mathrm{a}$ & $296.69 \mathrm{a}$ \\
1000 & $270.30 \mathrm{a}$ & $298.47 \mathrm{~b}$ \\
1500 & $296.00 \mathrm{a}$ & $339.09 \mathrm{~b}$ \\
2500 & $340.82 \mathrm{a}$ & $321.13 \mathrm{a}$ \\
\hline
\end{tabular}

Note. Means followed by the same vertical letter do not differ through Tukey's test at 5\% probability.

Regarding the foliar tissue thickness in the regions close to the central nervure of the leaf of the cotton plant genotypes, Table 2, there was no significant difference between the genotypes in any of the parameters assessed. The MC doses influenced the adaxial epidermis, having a quadratic adjustment of the mean values obtained and according to the equation, in the calculated dose of $1243.5 \mathrm{~mL} \mathrm{ha}^{-1}$ there was a larger reduction of the adaxial epidermis in the genotypes, $6.33 \%$ when compared to the witnesses. The abaxial epidermis was not influenced by the $\mathrm{MC}$ doses. There was interaction of the $\mathrm{MC}$ doses $\times$ genotypes for the thickness of the palisade parenchyma, lacuna parenchyma and total thickness (Tables 2.1, 2.2 and 2.3) respectively.

Table 2. Thickness of the parameters $(\mu \mathrm{m})$ of the region close to the central nervure (nervural) of the genotypes of herbaceous cotton plant due to the ascending doses of Mepiquat chloride. Selvíria-MS, agricultural year 2013. The data regarding the genotypes were expressed based on the average of all doses within each genotype. The data for the doses were expressed as the mean of the genotypes within the same dose

\begin{tabular}{llllll}
\hline Genotypes & Adaxial epidermis & Abaxial epidermis & Palisade parenchyma & Lacuna Parenchyma & Total Thickness \\
\hline FMT 701 & $24.47 \mathrm{a}$ & $18.94 \mathrm{a}$ & $161.02 \mathrm{a}$ & $111.04 \mathrm{a}$ & $310.69 \mathrm{a}$ \\
Fibermax 966 & $23.99 \mathrm{a}$ & $20.96 \mathrm{a}$ & $153.65 \mathrm{a}$ & $111.76 \mathrm{a}$ & $301.77 \mathrm{a}$ \\
Doses & & & & 323.16 \\
0 & 24.28 & 20.99 & 162.63 & 114.95 & 274.49 \\
500 & 23.65 & 18.99 & 137.45 & 96.44 & 281.33 \\
1000 & 23.24 & 20.52 & 157.51 & 102.34 & 328.47 \\
1500 & 23.48 & 19.45 & 164.33 & 126.22 & 323.70 \\
2500 & 26.49 & 19.81 & 164.76 & 117.05 & 47.22 \\
SD & 4.65 & 10.12 & 58.73 & 30.74 & 15.42 \\
CV (\%) & 19.22 & 50.73 & 37.33 & 27.60 & . \\
\hline
\end{tabular}

Note. Means followed by the same vertical letter do not differ through Tukey's test at 5\% probability. SD: Standard deviation. CV (\%): Coefficient of variation.

According to the results obtained in Tables 2.1, 2.2 and 2.3, it was confirmed that regarding the thickness of the palisade parenchyma, lacuna parenchyma and total foliar thickness, there was difference between the genotypes of the witness plants, where FMT 701 showed larger thickness of the palisade parenchyma, lacuna parenchyma and total foliar thickness. The thickness of the lacuna parenchyma and the total foliar thickness also differed 
from the genotypes in the dose of $2500 \mathrm{~mL} \mathrm{ha}^{-1}$, and this dose increased the thickness of the lacuna parenchyma and the total foliar thickness of Fibermax 966, and decreased the thickness of FMT 701.

In FMT 701, all the MC doses decreased the thickness of the palisade parenchyma, lacuna parenchyma and total foliar thickness. The dose of $500 \mathrm{~mL} \mathrm{ha}^{-1}$ was the one that mostly decreased the thickness of both the palisade parenchyma and the lacuna parenchyma, $27.12 \%$ and $33.41 \%$, respectively. Regarding the total foliar thickness of FMT 701, in the calculated dose of $1447 \mathrm{~mL} \mathrm{ha}^{-1}$ there was the smallest total foliar thickness, $14.74 \%$ smaller than that of the witnesses. On the other hand, in Fibermax 966 the thickness of the palisade parenchyma, lacuna parenchyma and total foliar thickness increased due to the MC doses, and in the dose of $2500 \mathrm{~mL} \mathrm{ha}^{-1}$ there was a larger thickness of the palisade parenchyma, lacuna parenchyma and foliar thickness, $20.12 \%, 27.45 \%$ and $20 \%$.

Table 2.1. Unfolding of the interaction of increasing doses of mepiquar chloride $\times$ herbaceous cotton genotypes, refers to the leaves palisade parenchyma (nervural) collected at 80 DAE. Selvíria-MS, Agricultural year 2013

\begin{tabular}{lll}
\hline Doses & FMT 701 & Fibermax 966 \\
\hline 0 & $186.33 \mathrm{a}$ & $138.92 \mathrm{~b}$ \\
500 & $135.79 \mathrm{a}$ & $139.11 \mathrm{a}$ \\
1000 & $167.42 \mathrm{a}$ & $147.61 \mathrm{a}$ \\
1500 & $159.96 \mathrm{a}$ & $168.70 \mathrm{a}$ \\
2500 & $155.60 \mathrm{a}$ & $173.92 \mathrm{a}$ \\
\hline
\end{tabular}

Note. Means followed by the same vertical letter do not differ through Tukey's test at $5 \%$ probability.

Table 2.2. Unfolding of the interaction of increasing doses of mepiquar chloride $\times$ herbaceous cotton genotypes, refers to the leaves lacuna parenchyma (nervural) collected at 80 DAE. Selvíria-MS, Agricultural year 2013

\begin{tabular}{lll}
\hline Doses & FMT 701 & Fibermax 966 \\
\hline 0 & $134.57 \mathrm{a}$ & $95.33 \mathrm{~b}$ \\
500 & $89.61 \mathrm{a}$ & $103.28 \mathrm{a}$ \\
1000 & $100.64 \mathrm{a}$ & $104.05 \mathrm{a}$ \\
1500 & $127.69 \mathrm{a}$ & $124.75 \mathrm{a}$ \\
2500 & $102.69 \mathrm{a}$ & $131.41 \mathrm{~b}$ \\
\hline
\end{tabular}

Note. Means followed by the same vertical letter do not differ through Tukey's test at $5 \%$ probability.

Table 2.3. Unfolding of the interaction of increasing doses of mepiquar chloride $\times$ herbaceous cotton genotypes, refers to the total thickness (nervural) of leaves collected at 80 DAE. Selvíria-MS, Agricultural year 2013

\begin{tabular}{lll}
\hline Doses & FMT 701 & Fibermax 966 \\
\hline 0 & $367.76 \mathrm{a}$ & $278.56 \mathrm{~b}$ \\
500 & $266.69 \mathrm{a}$ & $282.29 \mathrm{a}$ \\
1000 & $283.08 \mathrm{a}$ & $279.58 \mathrm{a}$ \\
1500 & $332.45 \mathrm{a}$ & $324.49 \mathrm{a}$ \\
2500 & $303.47 \mathrm{a}$ & $343.94 \mathrm{~b}$ \\
\hline
\end{tabular}

Note. Means followed by the same vertical letter do not differ through Tukey's test at $5 \%$ probability.

Based on the results shown in Table 3, the genotype FMT 701 presented higher rate of liquid photosynthesis (A), higher conductance (gs) and higher internal carbon concentration (Ci) than Fibermax 966. It can be seen that the MC doses decreased the liquid photosynthesis rate, the internal concentration of $\mathrm{CO}_{2}$ and the stomatal conductance of the cotton plant genotypes. There was interaction of the doses of $\mathrm{MC} \times$ genotypes for all characteristics assessed (Tables 3.1, 3.2 and 3.3) respectively. 
Table 3. Mean values of the liquid photosynthesis $\left(\mathrm{A}-\mu \mathrm{mol} \mathrm{CO} \mathrm{Cm}^{-2} \mathrm{~s}^{-1}\right)$, stomatal conductance $\left(\mathrm{g}_{\mathrm{s}}-\mathrm{mol}_{2} \mathrm{O}\right.$ $\left.\mathrm{m}^{-2} \mathrm{~s}^{-1}\right)$, internal concentration of $\mathrm{CO}_{2}\left(\mathrm{C}_{\mathrm{i}}-\mu \mathrm{mol} \mathrm{CO} \mathrm{CO}_{2} \mathrm{~mol} \mathrm{ar}^{-1}\right)$ Number of stoma of the adaxial foliar surface $\left(\mathrm{mm}^{2}\right)$ and the Number of stoma of the abaxial foliar surface $\left(\mathrm{mm}^{2}\right)$, of leaves of genotypes of herbaceous cotton plant due to ascending doses of Mepiquat choride. Selviria-MS, agricultural year 2013. The data regarding the genotypes were expressed based on the average of all doses within each genotype. The data for the doses were expressed as the mean of the genotypes within the same dose

\begin{tabular}{llllll}
\hline Genotypes & $\mathrm{A}$ & $\mathrm{g}_{\mathrm{s}}$ & $\mathrm{C}_{\mathrm{i}}$ & Number of stoma (adaxial) & Number of stoma (abaxial) \\
\hline FMT 701 & $151.41 \mathrm{a}$ & $36.67 \mathrm{a}$ & $280.60 \mathrm{a}$ & $92.73 \mathrm{a}$ & $158.84 \mathrm{a}$ \\
Fibermax 966 & $107.07 \mathrm{~b}$ & $33.52 \mathrm{~b}$ & $227.22 \mathrm{~b}$ & $111.05 \mathrm{a}$ & $199.57 \mathrm{~b}$ \\
Doses & & & & & \\
0 & 155.25 & 39.23 & 301.41 & 117.36 & 153.15 \\
500 & 139.34 & 39.91 & 266.95 & 95.79 & 171.05 \\
1000 & 129.07 & 34.82 & 262.96 & 67.89 & 151.58 \\
1500 & 118.47 & 32.63 & 231.55 & 105.26 & 161.57 \\
2500 & 104.06 & 28.89 & 206.68 & 123.15 & 156.84 \\
SD & 8.65 & 4.34 & 23.91 & 29.76 & 49.53 \\
CV (\%) & 6.70 & 12.37 & 9.42 & 29.21 & 27.64 \\
\hline
\end{tabular}

Note. Means followed by the same vertical letter do not differ through Tukey's test at $5 \%$ probability. SD: Standard deviation. CV (\%): Coefficient of variation.

According to the results obtained in Tables 3.1, 3.2 and 3.3, in FMT 701 the dose that most reduced the liquid photosynthesis $(\mathrm{A})$, stomatal conductance $\left(\mathrm{g}_{\mathrm{s}}\right)$ and internal concentration of $\mathrm{CO}_{2}\left(\mathrm{C}_{\mathrm{i}}\right)$ was that of $2500 \mathrm{~mL} \mathrm{ha}^{-1}$, in approximately $39.55 \%, 36.41 \%$ and $40.02 \%$, respectively.

In the Fibermax 966, for the liquid photosynthesis (A), Table 3.1, there was a quadratic adjustment of the mean values obtained and according to the equation, in the calculated dose of $1923 \mathrm{~mL} \mathrm{ha}^{-1}$ there was a larger reduction of the photosynthetic rate of $(28.44 \%)$. For the stomatal conductance $\left(\mathrm{g}_{\mathrm{s}}\right)$, Table 3.2 , the dose of $1500 \mathrm{~mL} \mathrm{ha}^{-1} \mathrm{was}$ the most reduced in Fibermax 966, in $22.59 \%$. The only dose of CM that increased stomatal conductance was 500 $\mathrm{mL} \mathrm{ha}^{-1}$ at around $10 \%$. For the internal concentration of $\mathrm{CO}_{2}\left(\mathrm{C}_{\mathrm{i}}\right)$ in Fibermax 966, Table 3.3, there was a quadratic adjustment of the mean values obtained and according to the equation, in the calculated dose of 1950 $\mathrm{mL} \mathrm{ha}^{-1}$ there was a larger reduction of (Ci) of $26.55 \%$.

Regarding the number of stoma of the leaves of the cotton plant genotypes (Table 3), the doses influenced the number of adaxial stoma. There was a quadratic adjustment of the mean values obtained and according to the equation, in the calculated dose of $1158.6 \mathrm{~mL} \mathrm{ha}^{-1}$ there was the greatest reduction in the number of adaxial stoma, around $26 \%$ when compared to the witnesses. There was significant difference between the genotypes only for the number of abaxial stoma, with a higher value in Fibermax 966.

Table 3.1. Unfolding of the interaction of increasing doses of mepiquar chloride $\times$ herbaceous cotton genotypes, refers to the liquid photosynthesis $\left(\mathrm{A}-\mu \mathrm{mol} \mathrm{CO} \mathrm{CO}_{2} \mathrm{~m}^{-2} \mathrm{~s}^{-1}\right)$ of genotypes of herbaceous cotton plant at 71 DAE. Selvíria-MS, Agricultural year 2013

\begin{tabular}{lll}
\hline Doses & FMT 701 & Fibermax 966 \\
\hline 0 & $184.00 \mathrm{a}$ & $126.50 \mathrm{~b}$ \\
500 & $158.33 \mathrm{a}$ & $120.35 \mathrm{~b}$ \\
1000 & $156.53 \mathrm{a}$ & $101.60 \mathrm{~b}$ \\
1500 & $146.95 \mathrm{a}$ & $89.99 \mathrm{~b}$ \\
2500 & $111.22 \mathrm{a}$ & $96.90 \mathrm{~b}$ \\
\hline
\end{tabular}

Note. Means followed by the same vertical letter do not differ through Tukey's test at $5 \%$ probability. 
Table 3.2. Unfolding of the interaction of increasing doses of mepiquar chloride $\times$ herbaceous cotton genotypes, refers to the stomatal conductance $\left(\mathrm{g}_{\mathrm{s}}-\mathrm{mol} \mathrm{H} \mathrm{H} \mathrm{m}^{-2} \mathrm{~s}^{-1}\right)$ of genotypes of herbaceous cotton plant at 71 DAE. Selvíria-MS, Agricultural year 2013

\begin{tabular}{lll}
\hline Doses & FMT 701 & Fibermax 966 \\
\hline 0 & $41.82 \mathrm{a}$ & $36.65 \mathrm{a}$ \\
500 & $38.85 \mathrm{a}$ & $40.97 \mathrm{a}$ \\
1000 & $39.21 \mathrm{a}$ & $30.43 \mathrm{~b}$ \\
1500 & $36.89 \mathrm{a}$ & $28.37 \mathrm{~b}$ \\
2500 & $26.59 \mathrm{a}$ & $31.19 \mathrm{a}$ \\
\hline
\end{tabular}

Note. Means followed by the same vertical letter do not differ through Tukey's test at 5\% probability.

Table 3.3. Unfolding of the interaction of increasing doses of mepiquar chloride $\times$ herbaceous cotton genotypes, refers to the internal concentration of $\mathrm{CO}_{2}\left(\mathrm{C}_{\mathrm{i}}-\mu \mathrm{mol} \mathrm{CO}_{2} \mathrm{~mol} \mathrm{ar}^{-1}\right)$ of genotypes of herbaceous cotton plant at 71 DAE. Selvíria-MS, Agricultural year 2013

\begin{tabular}{lll}
\hline Doses & FMT 701 & Fibermax 966 \\
\hline 0 & $340.30 \mathrm{a}$ & $262.51 \mathrm{~b}$ \\
500 & $280.46 \mathrm{a}$ & $253.45 \mathrm{a}$ \\
1000 & $297.62 \mathrm{a}$ & $228.31 \mathrm{~b}$ \\
1500 & $280.52 \mathrm{a}$ & $182.57 \mathrm{~b}$ \\
2500 & $204.10 \mathrm{a}$ & $209.27 \mathrm{a}$ \\
\hline
\end{tabular}

Note. Means followed by the same vertical letter do not differ through Tukey’s test at 5\% probability.

\section{Discussion}

The (Figure 1) confirmed all the statistical results obtained related to the thicknesses of the (internervural) part of the leaves of the cotton plant genotypes. Based on these images, the difference between the genotypes of the witness plants was clearly seen, where FMT 701 showed larger thickness of the abaxial epidermis (eb), palisade parenchyma (pp), lacuna parenchyma (lp) and total thickness than did Fibermax 966. In FMT 701 the MC doses tended to decrease the adaxial epidermis (ed), abaxial epidermis (eb), palisade parenchyma (pp), lacuna parenchyma (lp) and the leaf total thickness. In Fibermax 966 there was a reduction in the doses only for the thickness of the adaxial epidermis (de). The abaxial epidermis (be), palisade parenchyma (pp), lacuna parenchyma (lp) and foliar total thickness tended to increase due to the MC doses.

The (Figure 2) also confirmed the statistical results obtained related to the thicknesses of the nervural part of the leaves of the cotton plant genotypes. It was clearly observed that the witness of FMT 701 indeed showed larger thickness of the palisade parenchyma (pp), lacuna parenchyma (lp) and leaf total thickness than did the witness of Fibermax 966. The total thickness of the FMT 701 genotype decreased due to the MC doses, whereas in Fibermax 966 the doses increased the leaf total thickness. It also became clear that in the dose of $2500 \mathrm{~mL} \mathrm{ha}^{-1}$ the Fibermax 966 genotype showed larger thickness of the palisade parenchyma (pp), lacuna parenchyma (lp) and total thickness.

The internervural part of the leaf comprehends the region between the central nervure and the foliar border (Metcalfe, 1960). The leaf lamina, in general, presents two surfaces: the adaxial face (upper) and the abaxial face (lower). The epidermis is a continuous coating tissue with distribution covering the entire leaf. In the different species, the number of layers forming the foliar epidermis can range from uni- to multi-serial. Its variation also refers to the shape of the cells, their arrangement of the stoma, the morphology and the arrangement of the trichomes (Menezes et al., 2003).

According to Figures 1 and 2, it was possible to observe that the cross sections of the leaf lamina showed the adaxial and abaxial parts unstratified, with smaller cells on the abaxial face, with dorsiventral mesophyll composed of palisade and lacuna parenchyma. The palisade parenchyma is turned to the adaxial part and the lacuna parenchyma is turned to the abaxial part. The palisade parenchyma is composed of only one layer of long palisade cells, spaced from each other, rich in chloroplasts, lying perpendicularly to the surface of the leaf lamina, taking approximately half the structure. The lacuna parenchyma is composed of irregular cells, showing from 3 to 5 layers of cells laying in parallel to the surface of the epidermis cells, with an extensive system of intercellular spaces where water steam and carbon dioxide are kept. Thus, this structure allows a great surface of 
cells to be in contact with the existing air within the leaf, enabling the use of carbonic gas in the photosynthetic process (Damião Filho, 1993). Regarding the palisade parenchyma, in the literature its specializations refer to the efficiency of photosynthesis. Most chloroplasts are found in cells of the palisade parenchyma due to the elongated shape and to the arrangement of the cells, allowing the maximum capture of light (Appezzatto-da-Glória \& Carmello-Guerreiro, 2003).

According to the results achieved in the internervural region and in the central nervure of the cotton plant genotypes, it became evident that the MC doses in the internervural region decreased the adaxial epidermis, abaxial epidermis, palisade parenchyma, lacuna parenchyma and foliar total thickness of the FMT 701 genotype. In the Fibermax 966 genotype, the opposite happened: the MC doses tended to increase all the parameters assessed, except for adaxial epidermis, which was also decreased due to the MC doses.

In the nervural region, the doses were significant for: the adaxial epidermis, decreasing it in both genotypes; the adaxial epidermis, decreasing it in both genotypes; for the palisade parenchyma, lacuna parenchyma and total thickness of the genotypes, decreasing them in FMT 701 and increasing in Fibermax 966. The abaxial epidermis was not influenced by the doses. It is worth pointing out that although the MC doses have acted so distinctively in the genotypes, there was significant difference between each other only for the foliar total thickness of the internervural part, with a higher value in FMT 701.

The reduction caused by the MC doses in the palisade parenchyma and in the lacuna parenchyma of the leaves of the FMT 701 genotype was enough to interfere in the photosynthetic rate and in the internal concentration of $\mathrm{CO}_{2}$ of that genotype, reducing them too (Table 3). In a general view, FMT 701 showed the lowest photosynthetic rate and a larger internal concentration of $\mathrm{CO}_{2}$ than does Fibermax 966.

That the MC doses have influenced the photosynthetic rate and the internal concentration of $\mathrm{CO}_{2}$ of the cotton plant genotypes may be closely related to the fact that the doses caused the reduction in the number of adaxial stoma of the genotypes (Table 3), once that the stoma is a structure that allows the communication between the internal part of the plant and the atmosphere (El-Sharkawy et al., 1985). According to Angelocci (2002), the control of the inflow and outflow of $\mathrm{CO}_{2}$ and water of the plant occurs by means of the alteration in the stomata opening, due to transpiration, causing foliar cooling. Hence, the more transpiration, the higher will be the leaf cooling. Complementarily, there is a wide variation in the number of stoma per area among the species, what influences in the regulation of the gas changes.

The present result corroborates with Reddy and Hodges (1996), once that according to them, the application of MC decreased the liquid photosynthetic rate in $25 \%$, with loss of the photosynthetic capacity. Hodges et al. (1991) observed that the photosynthesis seems to be more effective due to the reduction of photorespiration in plants treated with MC; however, the response depends on the room temperature. According to the authors, the effect of the product over the photosynthesis appears 48 hours after the application, remaining for about three weeks. According to Kerby et al. (1993), the photosynthetic rate is decreased in the treatments undergoing MC, once that there is a reduction in the activity of the ribulose 1,5-bisphosphate carboxylase enzyme, which is involved in the photosynthesis. That is because the competition between the vegetative and productive growth for photoassimilates is decreased by the action of MC (Cothren \& Oosterhuis, 1993).

The results obtained by Gausman et al. (1979) corroborate with those obtained in the present experiment for the Fibermax 966 genotype. According to them, the applications of different concentrations of MC result in the increase in the leaf thickness, reduction of the foliar area, more elongated palisade cells and a greater number of cells of the lacuna parenchyma. They still observed a greater concentration of chlorophyll, what indicates a possible change in the energy relations within the cell, thus influencing upon photosynthetic efficiency.

In this study, it is concluded that the MC doses interfere in the photosynthetic apparatus, reducing the liquid photosynthesis rate, stomatal conductance, internal concentration of $\mathrm{CO}_{2}$, as well the number of adaxial stoma of both genotypes. Overall, the witness plants of the FMT 701 genotype show the foliar thickness of the abaxial epidermis, palisade parenchyma, lacuna parenchyma and the total thickness denser than those of Fibermax 966. In the internervural region of the FMT 701 genotype, the MC doses reduced all the indexes related to the foliar thickness; however, in Fibermax 966 the doses tended to increase the thicknesses of the abaxial epidermis, palisade parenchyma, lacuna parenchyma and total thickness of FMT 701, whereas in Fibermax 966 the doses increased the thickness of the palisade parenchyma. It was not possible to establish in the same region a unique dose for each genotype that could influence in the same way all the variables studied, being genetic constitution a fundamental factor for such responses. 

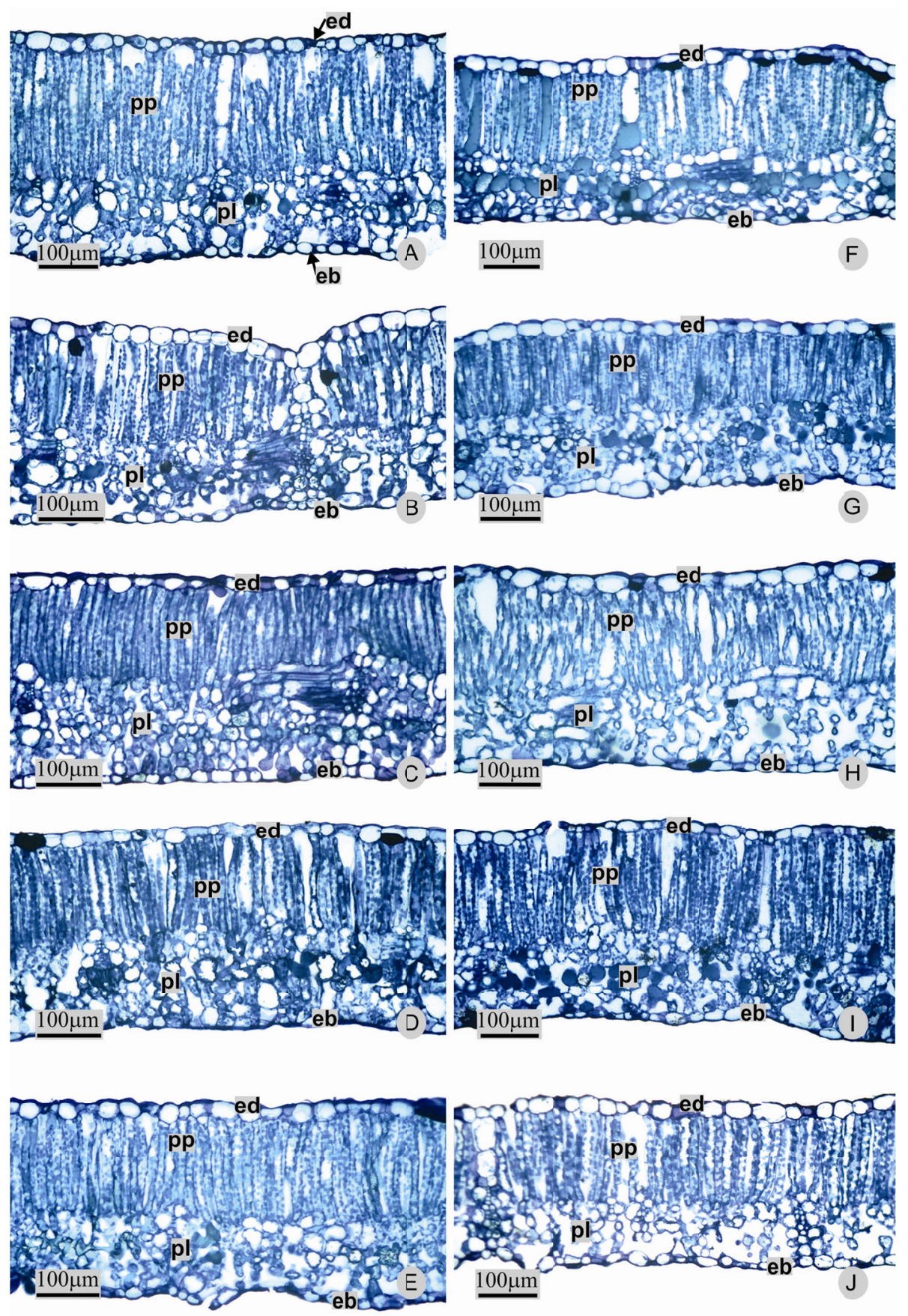

Figure 1. Cross-sections internervural region of leaves of herbaceous cotton genotypes (Gossypium hirsutum L. var. Latifolium Hutch) due to increasing doses of mepiquat chloride, Selvíria - MS, agricultural year 2013. A. Genotype FMT 701 (control). B. Genotype FMT 701 dose $500 \mathrm{ml} \mathrm{ha}^{-1}$. C. Genotype FMT 701 dose $1000 \mathrm{ml} \mathrm{ha}^{-1}$. D. Genotype FMT 701 dose $1500 \mathrm{ml} \mathrm{ha}^{-1}$. E. Genotype FMT 701 dose $2500 \mathrm{ml} \mathrm{ha}^{-1}$. F. Genotype Fibermax 966 (control). G. Genotype Fibermax 966 dose $500 \mathrm{ml} \mathrm{ha}^{-1}$. H. Genotype Fibermax 966 dose $1000 \mathrm{ml} \mathrm{ha}^{-1}$. I. Genotype Fibermax 966 dose $1500 \mathrm{ml} \mathrm{ha}^{-1}$. J. Genotype Fibermax 966 dose $2500 \mathrm{ml} \mathrm{ha}^{-1}$. (eb) abaxial epidermis; (ed) adaxial epidermis; (pp)palisade parenchyma; (pl) spongy parenchyma 

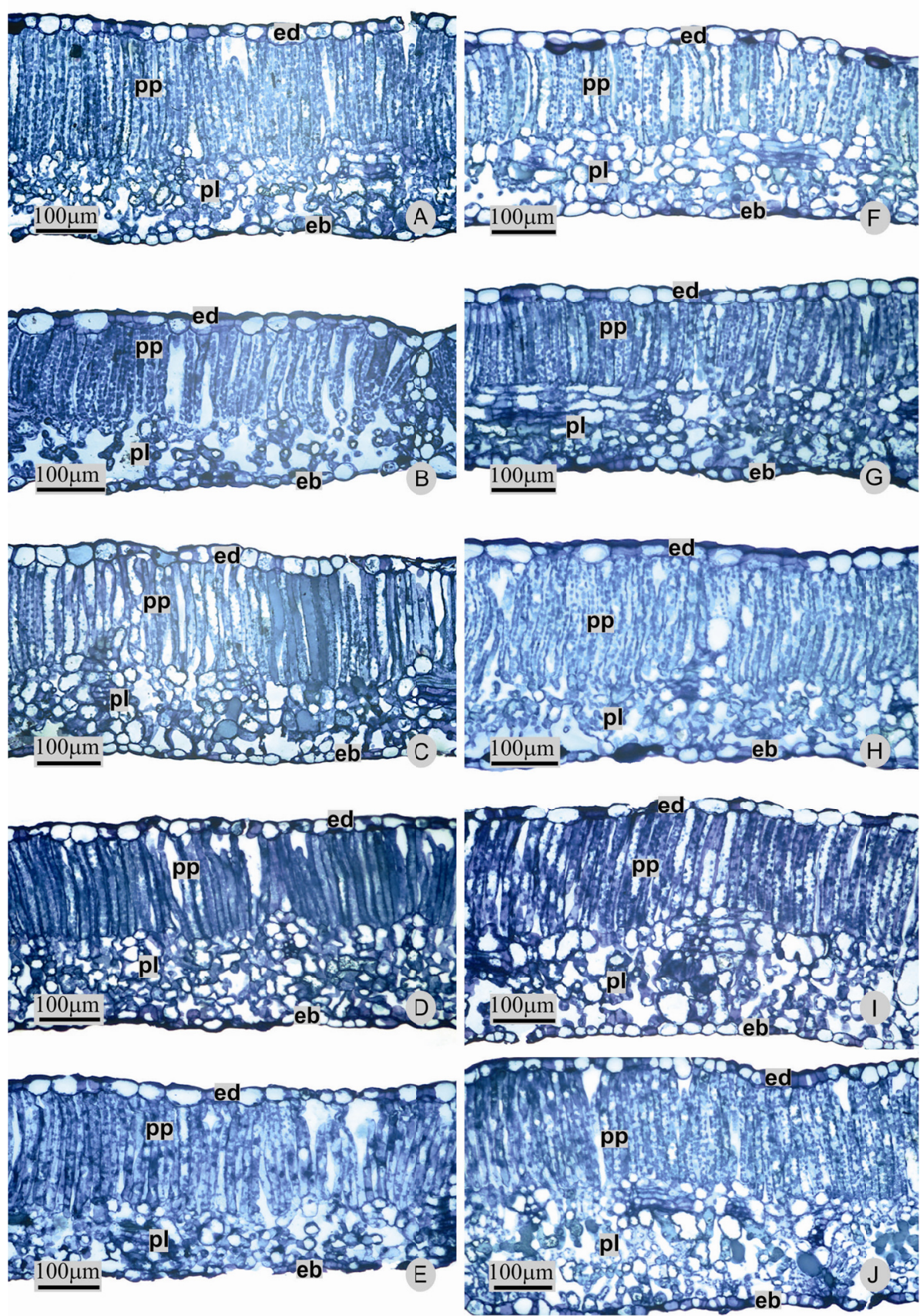

Figure 2. Cross-sections nervural region of leaves of herbaceous cotton genotypes (Gossypium hirsutum L. var. Latifolium Hutch) due to increasing doses of mepiquat chloride, Selvíria - MS, agricultural year 2013. A. Genotype FMT 701 (control). B. Genotype FMT 701 dose $500 \mathrm{ml} \mathrm{ha}^{-1}$. C. Genotype FMT 701 dose $1000 \mathrm{ml} \mathrm{ha}^{-1}$. D. Genotype FMT 701 dose $1500 \mathrm{ml} \mathrm{ha}^{-1}$. E. Genotype FMT 701 dose $2500 \mathrm{ml} \mathrm{ha}^{-1}$. F. Genotype Fibermax 966 (control). G. Genotype Fibermax 966 dose $500 \mathrm{ml} \mathrm{ha}^{-1}$. H. Genotype Fibermax 966 dose $1000 \mathrm{ml} \mathrm{ha}^{-1}$. I. Genotype Fibermax 966 dose $1500 \mathrm{ml} \mathrm{ha}^{-1}$. J. Genotype Fibermax 966 dose $2500 \mathrm{ml} \mathrm{ha}^{-1}$. (eb) abaxial epidermis; (ed) adaxial epidermis; (pp)palisade parenchyma; (pl) spongy parenchyma 


\section{Acknowledgements}

The first author (APP) received graduate scholarship from CAPES (Coordenação de Aperfeiçoamento de Pessoal de Nível Superior).

\section{References}

Angelocci, L. R. (2002). Água na planta e trocas gasosas/energéticas com a atmosfera: Introdução ao Tratamento Biofísico (p. 268). Piracicaba: USP.

Appezzato-Da-Glória, B., \& Carmello-Guerreiro, S. M. (2003). Anatomia Vegetal (p. 438). Viçosa: Editora UFV.

Barbosa, L. M., \& Castro, P. R. C. (1983). Desenvolvimento e produtividade de algodoeiros sob efeito de reguladores vegetais. Anais da Escola Superior de Agricultura “Luiz de Queiroz”, Piracicaba, 40(1), 33-86. https://doi.org/10.1590/S0071-12761983000100002

Bayer Cropscience. (2012). Sementes fibermax: FMX 966. São Paulo: [s.n.]. Retrieved January 30, 2013, from http://www.certificacaofibermax.com.br

Beltrão, N. E. de M., Azevedo, D. M. P. de., Vieira, D. J., \& Nóbrega, L. B. da. (1997). Recomendações técnicas e considerações gerais sobre o uso de herbicidas, desfolhantes e reguladores de crescimento na cultura do algodão. EMBRAPA-CNPA Documentos, 48 (p. 32) Campina Grande: EMBRAPA-CNPA.

Constable, G. A. (1994). Predicting yield responses of cotton to growth regulators. World cotton research Conference, 1, Brisbane. Proceedings... (pp. 3-5). Brisbane, Austrália: Challenging Future.

Cothren, J. T., \& Oosterhuis, D. M. (1993). Physiological impact of plant growth regulators in cotton. Beltwide cotton production research conferences, 1993, Dallas. Proceedings... (pp. 128-32) Memphis: National Cotton Council.

Damião Filho, C. F. (1993). Morfologia vegetal (p. 243). Jaboticabal: FUNEP/UNESP.

El-Sharkawy, M. A., Cock, M. J. H., \& Hernandez, A. D. P. (1985). Stomatal response to air humidity and its relation to stomatal density in a wide range of warm climate species. Photosynthesis Research, 7, 137-149. https://doi.org/10.1007/BF00037004

Ferreira, D. F. (2000). Análises estatísticas por meio do SISVAR para Windows versão 4.0. Reunião Anual da Região Brasileira da Sociedade internacional de Biometria, 45 (pp. 255-258). São Carlos. Anais... São Carlos: UFSCar.

Fundação, M. T. (2012). Cultivares convencionais: FMT 701. Cuiabá: [s.n.]. Retrieved October 15, 2013, from http://www.fundacaomt.com.br/algodao/cult.php?t=1\&tipo=fmt701

Gausman, H. W., Walter, H., Stein, E., Rittig, F. R., Leamer, R. W., Escobar, D. E., \& Rodriguez, R. R. (1979). Leaf $\mathrm{CO}_{2}$ (carbono dioxide) uptake and chlorophyll ratios of PIX (1, 1-dimethyl-piperidinium-chloride) treated cotton. Annual meeting plant growth regulator working group, 6., Las Vegas. Proceedings... (pp. 117-125). Las Vegas: Longmont.

Gomes, F. P. (2000). Curso de estatística experimental (p. 477). Piracicaba: USP.

Hernandez, F. B. T., Lemos Filho, M. A. F., \& Buzetti, S. (1995). Software HIDRISA e o balanço hídrico de Ilha Solteira (Série Irrigação, 1, p. 45). Ilha Solteira: FEIS/UNESP.

Hodges, H. F., Reddy, V. R., \& Reddy, K. R. (1991). Mepiquat chloride and temperature effects on photosynthesis and respiration of fruiting cotton. Crop Science, Madison, 31(5), 1301-8. https://doi.org/ 10.2135/cropsci1991.0011183X003100050044x

Johansen, D. A. (1940). Plant microtechinique (p. 523). New York: McGraw-Hill Company.

Kerby, T. A., \& Hake, K. (1993). Monitoring cotton's growth. In T. A. Kerby, K. Hake, \& S. Hake (Eds.), Cotton production (pp. 324-34). Oakland: ANR Publications.

Menezes, N. L., Silva, D. C., \& Pinna, G. F. A. M. de. F. (2003). In B. Apezzato-da-Glória \& S. M. Carmello-Guerreiro (Eds.), Anatomia vegetal (pp. 303-325). Viçosa: UFV.

Metcalfe, C. R. (1960). Anatomy of the monocotyledons: I. Gramineae. The Quarterly Review of Biology, 37(1), 49. https://doi.org/10.1086/403595

Raven, P. H., Evert, R. F., \& Eichhorn, S. E. (2007). Biologia vegetal (7th ed., p. 830). Rio de Janeiro: Guanabara. 
Reddy, A. R., Reddy, K. R., \& Hodges, H. F. (1996). Mepiquat chloride (PIX) induced changes in photosynthesis and growth of cotton. Plant Growth Regulation, 20(1), 179-183. https://doi.org/10.1007/BF00043305

Sakai, W. S. (1973). Simple method for differential staining of paraffin embedded plant material using toluidine blue O. Stain Technology, Baltimore, 48(5), 247-249. https://doi.org/10.3109/10520297309116632

Taiz, L., \& Zeiger, E. (2010). Plant Physiology (5th ed., p. 782). Sunderland Sinauer Associates.

\section{Copyrights}

Copyright for this article is retained by the author(s), with first publication rights granted to the journal.

This is an open-access article distributed under the terms and conditions of the Creative Commons Attribution license (http://creativecommons.org/licenses/by/4.0/). 